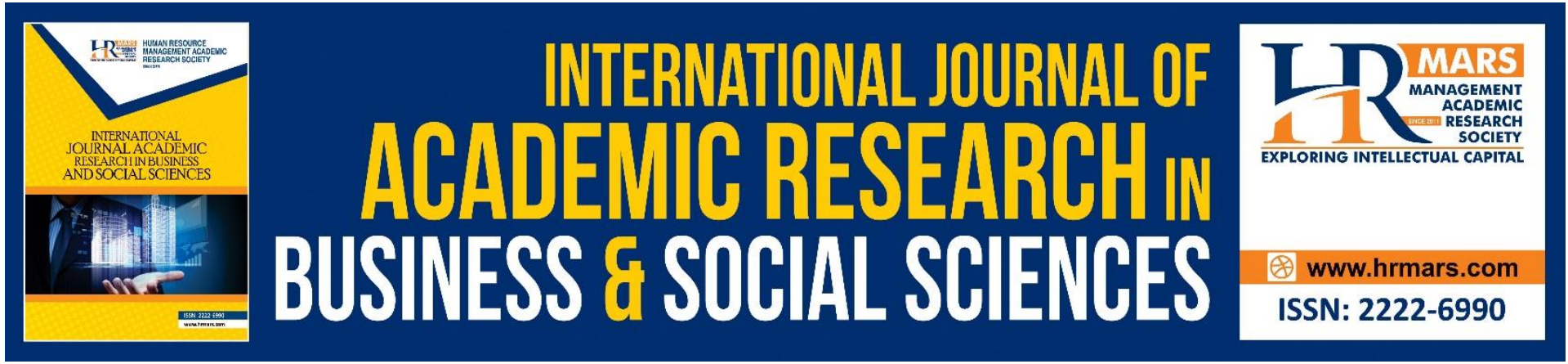

\title{
Malaysian Military Leadership: History, Values and Principles
}

\author{
Burhanuddin Jalal, Sayuti Ab Ghani, Amnah Saayah Ismail
}

To Link this Article: http://dx.doi.org/10.6007/IJARBSS/v11-i8/10757

DOI:10.6007/IJARBSS/v11-i8/10757

Received: 08 June 2021, Revised: 11 July 2021, Accepted: 01 August 2021

Published Online: 19 August 2021

In-Text Citation: (Jalal et al., 2021)

To Cite this Article: Jalal, B., Ghani, S. A., \& Ismail, A. S. (2021). Malaysian Military Leadership: History, Values and Principles. International Journal Academic Research in Business and Social Sciences, 11(8), 644-655.

Copyright: (c) 2021 The Author(s)

Published by Human Resource Management Academic Research Society (www.hrmars.com)

This article is published under the Creative Commons Attribution (CC BY 4.0) license. Anyone may reproduce, distribute, translate and create derivative works of this article (for both commercial and non-commercial purposes), subject to full attribution to the original publication and authors. The full terms of this license may be seen

at: http://creativecommons.org/licences/by/4.0/legalcode

Vol. 11, No. 8, 2021, Pg. 644 - 655

http://hrmars.com/index.php/pages/detail/IJARBSS

JOURNAL HOMEPAGE

Full Terms \& Conditions of access and use can be found at http://hrmars.com/index.php/pages/detail/publication-ethics 


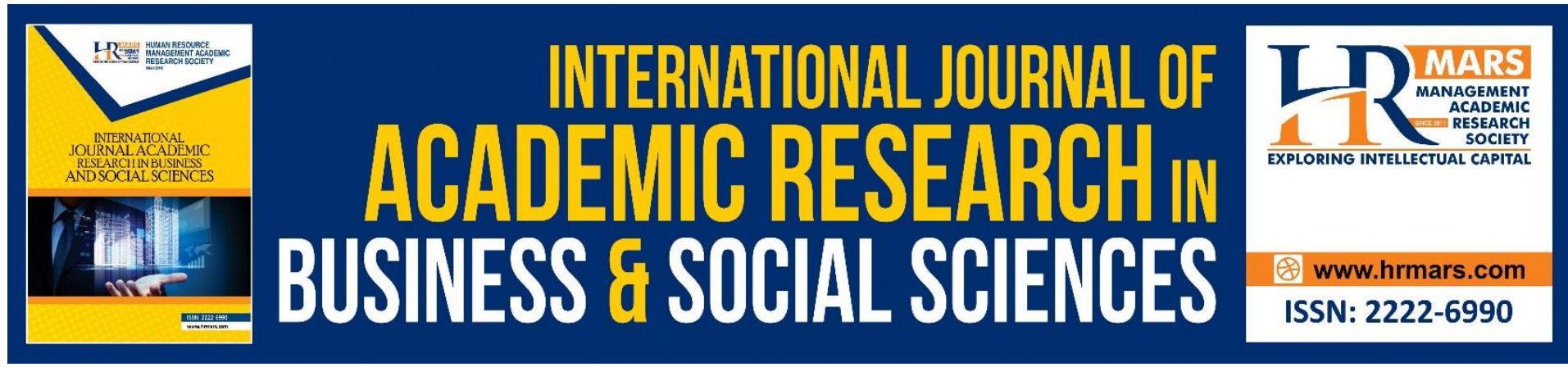

\title{
Malaysian Military Leadership: History, Values and Principles
}

\author{
Burhanuddin Jalal, Sayuti Ab Ghani, Amnah Saayah Ismail \\ National Defence University of Malaysia \\ Email: burhanuddin@upnm.edu.my
}

\begin{abstract}
The military is one of the world's oldest organisations, with its own leadership structure that has influenced other social organisation leadership patterns and styles. This article examines military leadership in terms of history, values, and principles that shape charismatic leadership. The data was gathered and analysed using library research, documentation research, and observations. In general, there are distinct characteristics in military leadership in various countries, including Malaysia. Military leadership in Malaysia has had a positive impact on the country's leadership as a result of military and civil service relations and the implementation of military operation other than war, which has contributed to the success of the Malaysian government's administration.
\end{abstract}

Keywords: Leadership, Military, Values, Defence, Principles

\section{Introduction}

In an organisation, there is leadership as well as a group that is led. Leadership is required to achieve a specific goal, and it goes through several specific processes to achieve a common goal. Drucker (1992) proposed a theory on the existence of modern organisations during the industrial revolution, and the organisation he refers to is a military organisation. According to Fayol (2013), a military organisation is the world's oldest organisation, and some key features of a military organisation are permanent, such as group loyalty, discipline, a loyal spirit of friends, and even hierarchy. Fayol (2013) listed some of these characteristics as management principles.

The term bureaucracy emerged in the $20^{\text {th }}$ century, which is also hierarchical and serves the interests of administrative tasks, and it also has similar features in military administration. The management and administration characteristics found in military organisations in general are the main feature found in the management aspects of humanitarian groups, and this is natural. This article attempts to explain aspects of military leadership and is a study of social groups or organisations that are generally authorized to use weapons, as well as security and war equipment assets to defend national security and sovereignty against enemy attacks. Apart from that, the discussion related to the aspects of 
military leadership also includes the history and background of the selected military organisation and discusses the values and principles adopted by the military organisation.

\section{Military: History, Values and Principles}

According to Keesing (1964), military organisations are distinct from other types of organisations. Its uniqueness stems from the background and early history of the organisation formation. Historically, the Persians has been noted as a nation with a military organisation and a high level of discipline. This is evidenced by the Persians' ability to control many countries in Europe, Africa, and Central Asia and occupy the region for 1000 years.

Military organisations in general have some characteristics or attributes that are similar or uniform, even within different countries. In general, the leadership of a military organisation is determined by values and principles that are aligned with the country's philosophy and ideology. Among the common values in military organisations are loyalty, duty, respect, selfless service, honour, integrity, and personnel course (www. azbea.org).

According to Collins (2008), the principles of military leadership are generally the same, namely: led by example, know yourself and seek improvement, live the army value, motivate the soldier, give direction to their movement, oversee the completion of the mission, train the soldier as a team, train for war, develop a sense of responsibility in the subordinate, ensure that each tasking understood, know your soldier and lookout their wellbeing, become technically and tactically proficient, seek responsibility and take your responsibility for your action.

Based on the American Army Doctrine (2000), several leadership principles are divided into three categories: be, know and do as shown in Table 1.

Table 1: Leadership Principles Based on American Army Doctrine

\begin{tabular}{|c|c|c|}
\hline BE & KNOW & DO \\
\hline $\begin{array}{l}\text { 1. Be committed to } \\
\text { military professional } \\
\text { ethics } \\
\text { 2. Loyalty to the } \\
\text { nation } \\
\text { 3. Selfless service } \\
\text { 4. Personal } \\
\text { responsibility } \\
\text { 5. Possess } \\
\text { professional } \\
\text { character traits } \\
\text { 6. Courage } \\
\text { 7. Competence } \\
\text { 8. Integrity } \\
\text { 9. Commitment } \\
\text { 10. Honesty }\end{array}$ & $\begin{array}{l}\text { 1. Know the four factors } \\
\text { of leadership, namely } \\
\text { follow, lead, } \\
\text { communication and } \\
\text { situational awareness } \\
\text { 2. Know yourself in } \\
\text { character strengths } \\
\text { and limitations } \\
\text { 3. Know the job and } \\
\text { responsibilities in } \\
\text { technical and tactical } \\
\text { expertise } \\
\text { 4. Know your unit team } \\
\text { includes teammates } \\
\text { 'strengths and skills, } \\
\text { unit expertise and unit } \\
\text { discipline }\end{array}$ & $\begin{array}{ll}\text { 1. } & \text { Direct } \\
\text { 2. } & \text { Set goals } \\
\text { 3. } & \text { Solve problems } \\
\text { 4. } & \text { Make decisions } \\
\text { 5. } & \text { Execute } \\
\text { 6. } & \text { Communicate } \\
\text { 7. } & \text { Coordination } \\
\text { 8. } & \text { Supervise } \\
\text { 9. } & \text { Evaluate } \\
\text { 10. } & \text { Motivate } \\
\text { 11. } & \text { Encourage } \\
\text { 12. } & \text { Improve morals } \\
\text { 13. } & \text { Develop spirit de corps } \\
\text { 14. } & \text { Coach } \\
\text { 15. } & \text { Counsel }\end{array}$ \\
\hline
\end{tabular}

Source: American Army Doctrine (2000). 
Based on Table 1 above, some features are similar to those presented by Henry Fayol as 14 management principles, namely:

1. Work division

2. Authority

3. Discipline

4. One instruction

5. One Order

6. Prioritize the interests of the organisation

7. Payment of wages

8. Centralisation

9. The chain of command

10. Arrangement

11. Balance

12. Personnel stability

13. Initiative

14. Spirit of togetherness

The above fourteen principles have been classified into administrative groups, human resource management, and management aspects. According to Shapiro (1956), the influence of military organisations in various organisations has inspired Henry Fayol to adapt the principles of military management in non-military organisations and to conform to the mechanisms of task execution and management in organisations and social societies.

\section{Definition of Military Leadership}

Military leadership is defined as the art of influencing and directing members to gain obedience, confidence, respect, loyalty, and close cooperation to accomplish a given task or mission. It is a combination of persuasion and instruction to become members under the direction to agree with their leader, even if it contradicts their wishes or desires at times. However, coercion may be necessary to achieve certain goals and missions. Military members will obey orders from a leader who possesses the character strength, knowledge and experience, rather than a weak or ineffective leader.

According to Field Marshall Montgomery (1961), military leadership is the ability and willingness to gather the strength of members for the same purpose and have the confidence to succeed. Meanwhile, Field Marshal William Slim (1956) stated, "Leadership is a projection of personality. It is a combination of persuasion and example that makes others willing to do what you want".

Furthermore, military leadership has been defined in a variety of ways. Taylor (2009) in his book 'Military Leadership-In Pursuit of Excellence,' defines military leadership as "an art and influence on the implementation of an action and provides guidance to the people of the world so that the led party has confidence and will, trust, honour, the compliance and obedience required to fulfil the responsibility, without much use of tools and time and there is compatibility to achieve the goal". 
In addition, British Defence Doctrine (2001) defined military leadership as, "the projection of personality and character to get subordinates to do what is required of them and to engender within them the confidence that breeds initiative and acceptance of risk and responsibility." While the American Army Doctrine (2000) provides a simpler definition of military leadership as, "a process by which an officer influences his soldiers to accomplish their mission".

Based on the given definition, military leadership consists of several important elements, specifically:

a. Art. The artistic element in leadership can be defined as competence, skill and proficiency in practising theory systematically and accurately based on existing experience.

b. Knowledge. The element of knowledge in military leadership is based on several military theories and doctrines that have been studied and comprehended and are capable of evaluating universal concepts, principles and techniques.

c. Influence and guide. Only through guidance and influence can humans be educated. Thus, to mobilize other humans, one's strengths and abilities in the aspect of influencing and guiding others are essential.

d. Humans. In aspects of military leadership, the human element is important. Military personnel will determine whether or not a goal is achieved. In military parlance, "it's not just the weapon; the person behind the weapon is more important". A good military leader will be able to meet both the needs of the military organisation and the established national interests.

e. Purpose. The element of purpose established in military leadership is the aspect of knowledge and art that can influence and lead the military organisation towards the desired goal.

Worthy to note that the aspect of power or authority is crucial in the future success of military leadership. The leader has power over the people or members under his leadership based on the established rules or laws. All parties, whether the leader or those led, are subject to the same rules or laws, which are then further strengthened by oath loyal to the military, and in the context of the Malaysian Armed Forces, all members are subject to the Malaysian Armed Forces Act 1972 as well as the Pledge of Allegiance. In essence, the military leadership will not be immune from acts of misconduct or abuse of power and all offences will be guided by existing rules, laws or acts.

\section{Military Leadership in Malaysia}

What about the military leadership situation in Malaysia? Does the military leadership in Malaysia have certain uniqueness, or are there values fundamental to the performance of duties or roles as a military organisation? What distinguishes it from other countries' military organisations? What are the values and principles practised by the Malaysian Armed Forces organisation? How do they influence its leadership pattern, and what is the form of leadership of the Malaysian military organisation?

The Malaysian Armed Forces (MAF) have a different history in comparison to other countries. The history of Malaysian Armed Forces began with a group of Malays in the Ceylon 
Rifle Regiment in the 18th century, followed by the participation of multiracial in the Malay State Volunteer Rifle in 1915. Furthermore, the establishment of a military force comprised of natives was initiated by the Malay's Rulers awareness and insistence at the time on the enlightenment of the utmost importance for natives to be in charge of the defence of their homeland. The proposal presented by the Sultan of Perak Sultan Alang Iskandar, Tuanku Yang Dipertuan Negeri Sembilan Tuanku Muhammad Ibnu Yam Tuan Antah, Raja Di Hilir Perak Sir Raja Chulan and Undang Rembau Dato 'Abdullah Haji Damat in the Federal Legislative Council Hall in 1920, and subsequently the Malay Regiment Bill was passed on June 23rd, 1933, as an Enactment No.11. A total of 25 Malay Muslims (see attached list name) were selected and trained under the supervision of Major Mac I.S Bruse. (Idris, 1983). The establishment began with the formation of the Malay Regimen on March 1st, 1933, in Haig Lines Port Dickson, Negeri Sembilan. Furthermore, after the British War Office approved the formation of a military force that had to be joined by locals, the Federation of Malaya handed Bill Act No. 11 through the British Council Consultative Committee (Wan Teh, 1993).

This regiment expanded into a full battalion known as the First Battalion Malay Regiment on January 1st, 1938. A second battalion was established on December 1st, 1941, six days before the Second World War in Malaya. Both battalions have shown their abilities in the war against the Japanese armies. By the outbreak of World War II, this regimen had grown to include two infantry battalions, and its members had fought to the death in the Battle of Singapore in 1942. This first battalion of the Malay Regiment, led by Lieutenant Adnan Saidi defended Opium Hill or 'Bukit Chandu' in Singapore (Wan Teh, 1993).

Following World War II, the country faced a Communist threat, prompting a state of emergency in 1948. This situation required the expansion of the armed forces. By 1950, the Malay Regiment's strength was increased to seven battalions. During the Emergency, the armed forces established multiracial forces such as the Federal Regiment and the Federal Armoured Car Squadron in 1952. After the country gained independence in 1957, the Malaysian Army was fully developed and ready to conduct counterinsurgency operations. Currently, the Malaysian Army force is being rapidly modernized as a conventional military force capable of facing future challenges (Wan Teh, 1993).

The Malaysian Armed Forces' excellence and success today are the results of various aspects, including leadership. Malaysia has experienced several difficult challenges, particularly security challenges or threats from within and outside the country. According to Baharuddin (2012), internal challenges, especially in terms of ethnic relations, have posed a threat to national security from the end of the Second World War in 1945 until now. These internal challenges, when measured based on conflict patterns, spans three eras: (1) 19451960 Conflict Era, (2) stable but Tense Era 1961-1970 and (3) Era of Social Cohesion 19712017. In terms of security challenges, Malaysia has faced several challenges including:
a. World War II -1939-1945.
b. First Malayan Emergency -1948-1960.
c. Confrontation with Indonesia -1963-1966.
d. Communist Terrorists -Insurgency -1968-1989.
e. Conventional Era -1990-2006.
f. The era of modernization - 2007-present. 
The Malayan Communist Party (MCP) Armistice agreement in Hatyai on 2 December 1989 marked the end of communism in Malaysia and the beginning of a new era for the Malaysian Armed Forces (MAF). Beginning in 1990, the MAF embarked on a transformation to become a fully equipped conventional fighting force capable of dealing with external threats. This philosophy is the focus of the government's efforts to restructure the three branches of the Malaysian armed forces into a credible force for the challenges of the 21st century. The conventional process, development, and modernization of the MAF are the result of the political stability and economic prosperity that followed the Cold War's end. The term 'conventional' refers to organisational and doctrinal change, whereas 'modernization' refers to the acquisition of high-tech weapons and equipment (Markas Tentera Darat, 2001).

To be a conventional Armed Forces, the MAF must be viewed as a combined force comprised of assets from the Army, Navy and Air Force should capable joining operating to ensure the success of any operation against any form of external threat. In the conventional warfare of the next century, there will no longer be a single service battle. Battles will be formed by joint operations conducted by two or more services.

In an effort to turn MAF into a conventional organisation, MAF organisations go through four stages of transformation, namely:

a. Implementation of the Ministry of Defence incorporated concept. This concept integrates the three MAF services with the civil service of the Ministry of Defence in order to facilitate overall management cooperation.

b. The second stage involves restructuring the governance and control mechanisms of the MAF's three components, including elements of the establishment of the highest command at the Armed Forces Headquarters, Joint Forces Headquarters, Army Headquarters, Navy Headquarters and Air Force Headquarters.

c. The third stage includes improving the inter-service membership ratio to achieve a balanced conventional fighter force.

d. The fourth stage of change is to correct the imbalance in the service, especially the Army service, where there is a personnel imbalance in the membership of combat units, combat assistance units, and combat assistance service units (Markas Angkatan Tentera, 2009).

Furthermore, the need to modernisation of the MAF has become apparent since the 1950s, during the insurgency subjugation era. Military assets, weapons and equipment have suffered from wear and tear, inefficiency and even outdated during the insurgency subjugation era. Awareness to replace with modern and sophisticated capital assets for all three services has become essential. Due to limited financial and budgetary resources, changes are made in a prudent and orderly manner. These changes happened in two stages which are domestic and international (Markas Angkatan Tentera, 2009).

The progress, transformation and leadership of the Armed Forces organisation in Malaysia are distinct from that of other countries because the military leadership organisation 
in Malaysia is comprised of military relations and civil services, also known as civil-military relations. This situation is different from other countries, especially Western countries that use the philosophy of liberal democratic administration, which demonstrates civil supremacy as a major factor in the country's administration. In Malaysia, the relationship between the government, the people and the military can be considered good and close. This good and close relationship can be described by the phrase 'the people and the army, they are hand in glove'.

Apart from that, the close relationship between the military and the government is exemplified by the existence of the Malaysian Armed Forces Act 1972, which was created to ensure and maintain the highest level of regulation and discipline for each member of the military. Besides, the close relationship between the military and the government can be translated through the existence of the Malaysian Armed Forces Act 1972, which was created to ensure and maintain the quality of regulation and discipline of each member of the military is at the highest level. It should be noted that the current military legal system is based on the previous British military legal system known as the Queen's Regulations for Army 1955, and the British legislation was adapted and enacted by Parliament and known as the Armed Forces Act 1972. Aside from that, members of the Malaysian Armed Forces abide by the Knights pledge, which is regarded as a symbol of loyalty to the country, namely:

a. Believe in God and piety to Him.

b. Loyal to the country and willing to sacrifice for its sake by never giving up.

c. Holds fast to military discipline and always upholds the heroism and honour of the military.

d. Prioritize the execution of tasks honestly and sincerely.

e. Keeping state secrets strictly.

According to Jalal (2018), the soldier's oath or pledge of allegiance contains elements of obedience to the government, firmness in carrying out or practising something and firmly keeping all military secrets.

Studies on military leadership or leadership in general will be incomplete without explaining the purpose, goals, nature and characteristics of such leadership. Therefore, among other things, the purpose of the study on military leadership in Malaysia has the following objectives:

a. The main purpose of the military leadership study is to evaluate the artistic aspect of knowledge that mobilize and influence military organisations towards the achievement of strategic goals and the efficient and effective execution of tasks.

b. The study's goal is to ensure that the organisation runs smoothly and that its members maintain a positive attitude and a strong soul that is always ready to perform military tasks, whether operational or administrative.

c. The nature of military leadership refers to the qualities that a leader should possess to carry out their functions and roles. Proclaim of the Knight Pledge clearly emphasizes the nature and values of leadership, morals, ethics, integrity, as well as creative, innovative, authoritative and wise qualities. 
d. The characteristics of military leadership in Malaysia are distinct because military leadership in Malaysia indirectly performs a dual function of duties, namely, directly participating in the military organisation and indirectly participating in society and community. More emphasis is placed on constructive autocratic leadership in military organisations, whereas constructive democratic leadership is more commonly practised in social and community settings.

\section{Strengthening Malaysia's Military Leadership}

Loyalty becomes the most important value in military leadership. In this regard, the importance of loyalty to the organisation, race and homeland is always emphasized in military life. Although there are times when certain cases illustrate the collapse of values, such as the events of Amin al-Maunah, Private Adam, or the presence of military personnel involved in criminal cases or other breaches of trust cases, these are isolated incidents that do not reflect the entire organisation or military leadership in general. From the standpoint of management, the member has violated some disciplinary principles, disobeyed the head's instructions or violated existing jurisdiction.

In the aspect of military leadership in Malaysia, history proves that there is no conflict in the country's leadership, and even when General Ibrahim Ismail was offered by Tun Razak, who was then Chairman of the National Movement Council or MAGERAN which was the governing body of Malaysia in times of emergency following the events of May 13, 1969, he apparently had rejected the offer. He stated that when the military leadership had taken over the leadership, the risk of returning power to the administration after the military took over was very difficult (Ibrahim Ismail, 1985). Literally, his concerns are well-founded because of the situation with military leadership in Indonesia where there was an Indonesian military uprising in 1948, and another military uprising due to dissatisfaction with the government that occurred in 1957, as well as the events that occurred on September 30, 1965, when the Indonesian military tried to seize power from the government (Fattah, 2005).

In the context of Malaysia, good relations between military leadership have been proven since the beginning of independence with the involvement of the Malaysian Armed Forces in the implementation of the concept of security and development or KESBAN, which is a strategy to develop society in various political, economic and social aspects (Abidin, 2015). Following the success of KESBAN, the Malaysian government and military leadership expanded the concept of security by implementing a comprehensive security strategy or HANRUH, which included the establishment of volunteer defence personnel, national service, Civil Defence and other programs to ensure HANRUH strategy can be achieved. The concept of total defence or HANRUH was developed in the 1980s as a model that incorporates defence resources, MAFs, government agencies and the private sector, and society. This strategy is related to total and integrated efforts undertaken by the government, non-government agencies, and the private sector, and it requires the commitment of people from all walks of life, not just the Armed Forces, in defending the country (Abdul Razak, 2009).

Furthermore, the success of the Malaysian Armed Forces in implementing the National Blue Ocean Strategy (NBOS), an approach used by Malaysia Prime Minister Dato 'Sri Najib Razak, demonstrates the strengthening of the Malaysian military leadership relationship. This NBOS approach prioritizes the development of new ideas that are both 
creative and innovative. The Ministry of Defence and the Malaysian Armed Forces have successfully implemented 22 initiatives, including community rehabilitation program, military community transformation program, Royal Malaysia Police (RMP) and MAF public patrol program, AMANITA program and my beautiful Malaysia program (Kementerian Pertahanan Malaysia, 2013).

Another achievement to be proud of is the Malaysian Armed Forces' participation in the success of the Malaysian government's National Service Training Program (NSTP) from 2004 to 2018. The character-building program aims to instil and strengthen patriotism in the younger generation, foster racial unity and national integration, and form a positive character based on pure values. This program does not function as a manpower deployment program and is not guided by any outside model as it is implemented according to the Malaysian way. During the period, a total of 926,999 participants were successfully trained (Kementerian Pertahanan, 2019).

Malaysia's military leadership commitment became apparent when the Ministry of Defence successfully presented the Defence White Paper in the Malaysian Parliament on December 2nd, 2019. The Defence White Paper (DWP) is a document that outlines the strategic direction and national defence planning for Malaysia. Unlike classified National Defence Policy documents, the DWP is an open document that can be accessed by the public and does not contain any confidential information. Both documents describe related national security assessments, defence postures, and defence capability development, but with different purposes and emphasis. The DWP, as an open document, informs the public that security is a serious matter that should not be taken lightly. The government has always been committed to protecting national interests by defending sovereignty and territorial integrity, but these efforts are subject to various risks, threats, and uncertainties stemming from the ever-changing security environment. There are three main objectives of the KPP: (1) to involve the people and stakeholders, (2) to assess the country's ever-changing strategic perspective and (3) to explore approaches to improve the country's defence capabilities and preparedness (Kementerian Pertahanan Malaysia, 2020).

Through the Defence White Paper (Ministry of Defence Malaysia, 2020), the government has identified 10 requirements to further enhance the country's defence capabilities, which include the following aspects:

a. Strengthen the defence intelligence of the Malaysian Armed Forces.

b. Develop the capability of cyber electromagnetic activity.

c. Enhance intelligence, surveillance, target procurement and reconnaissance capabilities

d. Develop network-centric operation.

e. Satellite communications to enhance joint command and control capabilities.

f. Maintain and improve the capability and operational tempo of the MAF Special Forces.

g. Maritime Domain - enhances maritime combat capability and maritime operational resilience capability.

h. Air Domain - air defence and air attack capabilities

i. Land Domain - increase firepower, mobility, communication, logistical capabilities; and develop amphibious abilities. 
The Malaysian military leadership continues to contribute to national defence and security through the full involvement of the Malaysian Armed Forces in combating the COVID19 pandemic, which began in December 2019. The Commander of the Malaysian Armed Forces, General Tan Sri Affendi Buang RMAF, stressed that the role and involvement of the Malaysian Armed Forces (MAF) in combating the COVID-19 pandemic is one of the obligations and commitments to the country and the people. The Malaysian Armed Forces are now more involved in curbing the COVID-19 pandemic by providing expertise and facilities owned by the MAF, especially expertise and health facilities, hospitals, doctors and paramedics. MAFs' tasks and roles in PKP phase 1, phase 2 and phase 3 are increasing as the Malaysian Ministry of Health $(\mathrm{MOH})$ requires the military's assistance in conducting surveillance on the Tightened Movement Control Order (Harian, 2021).

\section{Conclusion}

In summary, the 21st century is a time of turmoil, uncertainty, complexity and ambiguity, making effective military leadership very important. The environment is changing so rapidly that different measures are needed to address the various problems that arise when leading command and control-oriented military organisations. Therefore, military leadership today must maximize the use of modern management tools and current demands that may arise from the rapidly changing environment, thus broadening the perspective of military leadership today to improve the performance of individual members and military organisations as a whole.

\section{References}

Fattah, A. (2005). Demiliterisasi Tentera: Pasang Surut Politik Militer 1945 - 2004. Jakarta: LKiS Anon. (2000). Akta Angkatan Tentera Malaysia 1972. Kuala Lumpur: International Law Book service

American Army Doctrine. (2000). www.tradoc.army.mil Retrieve on 14 July 2021

Anon. (2021). Peranan ATM diperkukuh bendung COVID-19. Berita Harian, 12 Jun 2021

Abdul Razak, A. (2009). Konsep Pertahanan Menyeluruh Di Malaysia: Cabaran Dan Masa Depan Angkatan Tentera Darat. Tesis. Kuala Lumpur: Fakulti Sastera dan Sains Sosial, Universiti Malaya.

British Defence Doctrine. (2001). https://doi.org/10.1080/03071840108446718 retrieve on 16 July 2021.

Jalal, B. (2018). Dakwah askari di Malaysia. Nilai: Penerbit Universiti Sains Islam Malaysia. Drucker, P. (1992). Managing for the future. New York: Basic Books.

Fayol, H. (2013). General and industrial management. London: Martino Fine Books.

Ismail, I. (1985). Sudahkah kamu bertemu Mariam? Kuala Lumpur: Dewan Bahasa dan Pustaka.

Collins, J. M. (2008). Military strategy: Principles, practises and historical perspective. Washington: Potomac Books incorporated.

Keesing, F. F. (1964). Cultural anthropology. New York: Holt, Rinehart and Winston.

Kementerian Pertahanan Malaysia. (2013). National Blue Ocean Strategy- initiative under MINDEF and Armed Forces. Kuala Lumpur: Kementerian Pertahanan Malaaysia

Kementerian Pertahanan Malaysia. (2020). Kertas Putih Pertahanan. Kuala Lumpur: Kementerian Pertahanan Malaysia.

Kementerian Pertahanan Malaysia. (2020). Laporan Tahunan Kementerian Pertahanan 2019. Kuala Lumpur: Kementerian Pertahanan Malaysia. 
Kementerian Pertahanan. (2019). Laporan Tahunan Kementerian Pertahanan 2018. Kuala Lumpur: Kementerian Pertahanan Malaysia.

Markas Angkatan Tentera. (2009). Perisai Pertahanan Nasional. Kuala Lumpur: Markas Angkatan Tentera Malaysia.

Markas Tentera Darat. (2001). Tentera Darat menentang insurgensi. Kuala Lumpur: Markas Tentera Darat Malaysia.

Montgomery, Bernard Law. (1961). The Path to Leadership. London: Collins.

Taylor, R. T. (2009). Military leadership - in pursuit of excellence. Philadelphia: Westview Press.

Baharuddin, S. A. (2012). Modul Hubungan Etnik. Bangi: Penerbit Universiti Kebangsaan Malaysia

Shapiro, H. (1956). Man, culture and society. New York: Basic Books.

Teh, W. H. (1993). Perang Dunia kedua: Peranan Askar Melayu. Kuala Lumpur: Dewan Bahasa dan Pustaka.

William, S., \& Marshal, F. (1956). Defeat into Victory. New York: McKay.www. azbea.org. Retrieve on 15 July 2021. 